Current Aspects of the Neurosciences

Volume 2 


\title{
Current Aspects \\ of the Neurosciences
}

\author{
Volume 2
}

\section{Edited by \\ Neville N. Osborne}

Nuffield Laboratory of Ophthalmology

University of Oxford

Oxford OX2 $6 A W, U K$

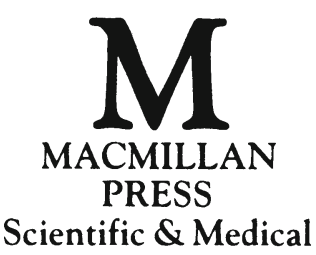


(C) The Macmillan Press Ltd 1990

Softcover reprint of the hardcover 1st edition 1990

All rights reserved. No reproduction, copy or transmission of this publication may be made without written permission.

No paragraph of this publication may be reproduced, copied or transmitted save with written permission or in accordance with the provisions of the Copyright, Design and Patents Act 1988, or under the terms of any licence permitting limited copying issued by the Copyright Licensing Agency, 33-4 Alfred Place, London WC1E 7DP.

Any person who does any unauthorized act in relation to this publication may be liable to criminal prosecution and civil claims for damages.

First published 1990

Published by

THE MACMILLAN PRESS LTD

Houndmills, Basingstoke, Hampshire RG21 2XS

and London

Companies and representatives

throughout the world

Filmset by Wearside Tradespools, Fulwell, Sunderland

British Library Cataloguing in Publication Data

Current aspects of the neurosciences.

Vol. 2

1. Man. Nervous system. Diseases

I. Osborne, Neville N. (Neville Nahash) 1942-

616.8

ISBN 978-1-349-11924-0 ISBN 978-1-349-11922-6 (eBook)

DOI 10.1007/978-1-349-11922-6 


\section{Contents}

Preface

1. Second Messengers in Neuronal Growth and Degeneration M. P. Mattson

2. Receptors Linked to Hydrolysis of Choline Phospholipids: the Role of Phospholipase D in a Putative Mechanism of Signal Transduction

K. Löffelholz

3. Pertussis Toxin-sensitive GTP-binding Proteins in Neuronal Tissues: Recent Insights into Expression and Function

G. Milligan

4. Regulation of Ion Channels and Neurotransmitter Release by Protein Kinase C

P. J. Conn

5. From Synapse to Genome: the Role of Intermediate-early Genes in Permanent Alterations in the Central Nervous System

H. A. Robertson and M. Dragunow

6. Platelet-derived Products and Adrenergic Neurotransmission $\ldots$ T. J. Verbeuren

7. Control of Exocytosis in Secretory Cells: the Adrenal Chromaffin Cell

A. J. O'Sullivan and R. D. Burgoyne

8. Neuropeptide Co-storage and Exocytosis by Neuronal Large Dense-cored Vesicles: How Good is the Evidence? R. L. Klein and A. K. Thureson-Klein 
9. Selective Ligands for Berzodiazapine Receptors: Recent Developments

D. J. Nutt

Index 


\section{Preface}

Current Aspects of the Neurosciences attempts to highlight new and fastmoving areas in neuroresearch through the eyes of the involved investigators. Thus, although each chapter is written from a relatively personal point of view, it contains new, up-to-date material and ideas that should be of immediate interest to the reader as well as providing background information of longer-term, archival interest. It is also hoped that each chapter will provide an overview of a research area together with theoretical and practical guidelines for future work.

Originally, the editor intended to produce the volumes annually. The immediate and positive response to Volume 1, however, has induced the editor to publish the volumes on a somewhat more rapid, albeit irregular, schedule.

As stated in the Preface to the first volume, the ever-increasing amount of data in the neurosciences is difficult to absorb and interpret. The area of research related to the generation of second messengers and subsequent actions on enzymes, proteins, channels, oncogenes, secretory processes, growth and differentiation is of particular interest at the present moment. It is this field of research that provides the focal point of this volume. 